\title{
Land redistribution in South Africa: Towards decolonisation or recolonisation?
}

\author{
Thembela Kepe \& Ruth Hall
}

\begin{abstract}
Contrary to populist political discourses, in South Africa the ruling party's approach to land policy is reproducing paternalistic relations that echo apartheid practices and represent the 'colonial present'. This reality stands in stark contrast to the initial aim of land reform, which was conceived as part of a larger project of decolonisation. The latest land redistribution strategy, the Proactive Land Acquisition Strategy, where the state remains the landowner, is no longer consistent with the project of decolonisation. This is because, we argue, land redistribution in South Africa has drifted away from the ideal of social justice; it increasingly displays symptoms of what the 'colonial present' and 'recolonisation'. Party politics, as well as the emergence of a challenge to the ruling party from the left, has prompted a more radical rhetoric, but one that co-exists with deeply conservative practices. This paper argues that the status quo represents a betrayal of the idea of land reform as decolonisation, and that a radical shift in policy and practice is needed in order to align it with a project of decolonisation in South Africa.
\end{abstract}

\section{Introduction}

The past four years have seen the resurgence of 'the land question' at the centre of national politics. Having been relegated to the backwaters of minor state programmes and having never attracted more than one percent of the national budget - land has become pivotal to party-political battles since the emergence of the Economic Freedom Fighters (EFF) in political contention in the run-up to the 2014 national elections. Potent beyond their numbers in Parliament, the EFF has successfully mobilised land as metaphor and symbol of economic disenfranchisement, of the failure of the ruling African National Congress (ANC) to bring about economic freedom or even decolonisation. Picking up on the critical discourses of the Rhodes Must Fall and later Fees Must Fall student movements, which have centred on the need to decolonise knowledge, institutions and the economy, the EFF has depicted land ownership in South Africa as being the product of colonial conquest and theft, and all white ownership as illegitimate. For South Africa to decolonise, goes the logic, first the land must be returned to the black African majority. 
In response to the EFF laying down this political gauntlet, the ANC has adapted and changed the way it talks about land, exposing ideological and strategic divisions within its own ranks. On 3 February 2017, Minister of Rural Development and Land Reform, Gugile Nkwinti, announced that the government was 'planning a "constitutional revolution" to fast-track land reform, including considering expropriation without compensation' (Bendile 2017a). Later that month, on 24 February 2017, President Jacob Zuma expressed similar sentiments, declaring 2017 the year of 'taking land back to the people' and vowing that his government would pursue land expropriation without compensation (Bendile 2017b). Following the dismal showing by the ANC in the local government elections in August 2016, the ANC entered 2017 with its proverbial back to the wall, and its clarion call, from the State of the Nation address onwards, was a promise of 'radical economic transformation'. Thus, radical moves on acquisition of land for land reform came to be poised as the ANC's answer to 'white monopoly capital' - the term popularised by the ANC and its allies in the Black First Land First grouping and others on 'paid twitter', on the advice of UK public relations firm Bell Pottinger.

In a bizarre twist, in March 2017, the ANC in Parliament voted against an EFF motion to amend Section 25 of the Constitution - the 'property clause' - so as to remove the requirement that the state pay 'just and equitable' compensation for land it expropriates. Offering its $6 \%$ of the parliamentary vote to the ANC, the EFF effectively called the ANC's bluff, forcing it to contradict the recent statements by both the President and the Minister by opposing the motion, in line with its own policy. This is just what ANC MPs did, led on by senior ANC leaders who spoke out against the motion, including Enoch Godongwana, chair of the ANC's Economic Transformation Committee. As noted by the media:

The African National Congress (ANC) said the state should pay fair compensation for land it acquires for distribution to the country's black majority, contradicting a suggestion by President Jacob Zuma that the constitution should be changed to allow for free [i.e. uncompensated] expropriation. (Mkokeli and Cohen 2017)

What all this adds up to can and should be debated. Does this signify the political importance of land or, ironically, its unimportance to the ruling party? We argue, in fact, it is the latter. Both the ruling party and its challenger from the political left have contracted complex debates about land into short slogans, with minimal if any detail, and have shown little interest in who gets the land, what rights they have and how they use it. The EFF has hardly seen fit to engage with the detail of land reform policy or implementation. Instead, it has ramped up the political discourse around land - as symbol, as identity and as citizenship.

Izwe Lami (The Land is Mine) was the EFF's election song, released ahead of the 2016 local government elections. As an alternative to the Pan Africanist Congress slogan 'Izwe Lethu' (The Land is Ours) of the 1960s, it shuns the inclusive 'ours' in favour of 'mine'. The main lyrics of the song that are repeated throughout are: 
Ngizolilwela izwe lami (I will fight for my land)

Yebo ngizolilwela bo (Yes I will fight for it)

Izwe lami, izwe lami (My land, my land) (Chorus)

'Land' translates as not only land in the material sense but also as 'country' in both isiXhosa/isiZulu ('izwe lam'/izwe lami and Afrikaans (my land). In this sense, narratives of taking back the land signify more than control over a physical entity or asset, but more profoundly refer to taking back the country or even being taken back by the country and therefore belonging and the restoration of citizenship (Krog 2015).

Through these deft uses of political discourse by the EFF, the ANC, meanwhile, has been exposed as defending the interests of white (and corporate) landowners and failing to listen to the legitimate demands of many of its own constituents for more decisive action to redistribute the wealth of the country.

\section{Decolonisation or recolonisation?}

Even though decolonisation can mean many things to different people, there appears to be some consensus that at its basic level it involves gaining independence from colonial powers, a process that visibly manifests through the coloniser's withdrawal from the colonies as well as the undoing of political and economic domination of the former colonies by the colonisers (Eze 2015). As Hack (2008) reminds us, decolonisation is often seen as not being only about the overall removal of the domination of the formerly colonised people within their geographical locations, and from their institutions, but it should include the mental emancipation of the victims of colonialism from the dominant ideas of the colonisers that might have caused colonised people to feel subservient and inferior. Whether it is feasible or not, Eze (2015) argues that the goal of decolonisation should include making it feasible for the formerly colonised people to return to their authentic selves.

Whatever conceptualisation of decolonisation exists, debate on this subject has largely focused on whether, and how, the process of decolonisation fulfils its goals as defined by the victims of colonisation. For the most part, scholarship has pointed to the unfulfilled promises of decolonisation, and even the insincerity of such processes, especially when there is an uncritical embrace of nominal decolonisation. Ndlovu-Gatsheni (2012) is critical of premature celebrations of decolonisation that overlook invisible hierarchies of political, economic, spiritual, linguistic and racial arrangements, to mention a few, that should contextualise the climate within which the struggle for decolonisation occurred. For this reason, Ndlovu-Gatsheni $(2012,74)$ suggests the concept of 'coloniality of power' that encourages critical thinking about colonialism and decolonisation beyond the mere takeover of power over the state's juridical and political boundaries. When decolonisation is limited to juridical-political approaches, he argues, this merely moves the formerly colonised people from 'global colonialism' to the current era of 'global coloniality' $(2012,74)$. 
In line with this thinking, South Africa's celebration of attaining liberal democracy at the end of apartheid is therefore seen as an illusion that yields neither decolonisation, nor social justice or freedom (Ndlovu-Gatsheni 2013; Eze 2015). Student movements under the 'Fees Must Fall' rubric re-animated 'decolonisation' as a central frame for political movements from 2015, often extending their demands beyond fee-free education to 'the return of the land', with 'the land' symbolising the continuation of the colonial present.

Some scholars who have reflected on the concept of decolonisation in South Africa have invoked two perceptive concepts to describe the status quo. First, partly influenced by the writings of Derek Gregory's book, The Colonial Present (2004), some scholars see the South African post-apartheid era as being dominated by the 'colonial present'. Using the case of the unfulfilled promise of land reform, and the tacit blessing that the state awards to the questionable and sometimes repressive activities of unelected traditional leaders, Fraser (2007) outlines a convincing argument about how Gregory's work in the Middle East resonates with post-apartheid South Africa. While the USA and Israel did not necessarily seek to establish colonies in the territories they occupied, what Gregory (2004) - in the case of the Middle East - and Fraser (2007) - in the case of South Africa - highlight, and call the 'colonial present', is that certain colonial-style relations tend to endure, persist and are even reactivated. These colonial-style relations should be seen for what they are: encompassing violence, dispossession and control by the dominant power (Harris 2004). As we show later in this paper, and in agreement with Fraser, the state's land reform strategies continue to keep control of the land and means of production in the hands of whites, corporate and even multinational capital, as well as black elites, while the majority rural black population holds insecure land rights and is often beholden to the state and whites for their use of the land as 'partners'. This constitutes the colonial present, even in the midst of land reform.

Second, some scholars, such as John Saul (2012) are even harsher in dismissing the idea of a decolonised South Africa. Saul argues that what exists in South Africa after colonialism and apartheid is actually 'false decolonisation' or even 'recolonisation' $(2012,588)$. Similar to Ndlovu-Gatsheni's $(2013,66)$ reference to decolonisation as 'illusions of liberation and myths of freedom', Saul (2012) believes that South Africa is not really liberated, as inequalities are manifested in terms of class, gender and expression of democratic voice. This is also consistent with what Achille Mbembe (2008) has argued, when he dismissed the notion of a decolonised, post-apartheid South Africa because this era has not translated into redistributive justice, because the majority of black people remain in poverty, with only limited control over their own labour and lives. Nowhere more are these arguments applicable than in the area of land rights and land reform.

\section{Land as symbol of continued colonisation}

Land has always been a central feature in both colonialism and decolonisation. This is because land was at the centre of colonial conquest, as well as a rallying symbol of resistance against colonialism. Thus, any discussion on decolonisation should acknowledge the importance of land, particularly its multiple meanings that include both land justice

\section{http://repository.uwc.ac.za}


and freedom in general (Kepe and Hall 2016). As Gutto (2014, 5) points out, land is a central feature of the 'means of social production and reproduction, and statehood'. In the case of South Africa not only is land important in thinking about post-apartheid land reform, but also about the broader agenda of emancipation from the legacy of colonialism. Atuahene $(2007,1432)$ frames this helpfully, when she argues that colonial and apartheid land dispossessions did not only rob African people of their land, but also resulted in what she terms 'property-induced invisibility' or 'social death'. Thus, land reform alone that focuses on returning land as a model of redress does not go far enough in addressing the dehumanising effects of colonial and apartheid land dispossessions (Levin, Kepe, and von Lieres 2016). This is why other meanings of land that look beyond land as a commodity are also crucial. Land reform in South Africa has not reversed the experience of land as a symbol of colonial and apartheid conquest, as well as of resistance against colonialism and apartheid. Rather, what can be observed in land reform thus far is what can be seen as the colonial present or continued colonisation.

There are two main angles to thinking about land as a symbol of colonial present that we believe are relevant to the discussion on decolonisation. These are the concepts of 'productive use' and 'trusteeship'. Both concepts were central in justifying colonial land dispossessions and are currently central in the trajectory of land reform in South Africa. In addition to invoking the idea of terra nullius (empty land) (Boisen 2017), colonists believed they were entitled to take land that they believed indigenous people were not making productive use of (Miller et al. 2010). Referring to land redistribution projects in South Africa, it has been reported that 'government has announced that it will confiscate unproductive farms and pass them on to those who can use them' (Ncana 2010). Attrition is to be expected - as was evident in the apartheid government's attempts to create a white commercial farming class in the mid-twentieth century - this threat to dispossess the 'beneficiaries' of land reform contradicts the government's professed commitment to secure tenure. While its legality is not clear, it seems consistent with the state's latest land redistribution strategy, the Proactive Land Acquisition Strategy (PLAS), where the state remains the owner of the land, and occupants can be made to leave if they fail to use their land productively (Kepe and Hall 2016, see also Minister Nkwinti, cited in Radebe 2012). Agricultural production is often seen as the most obvious use of arable land in rural areas of South Africa, and the state insists on 'productive use' of this land - usually meaning commercial production at scale (Kepe and Tessaro 2014). This pressure to make land 'productive' through activities that are imposed by the state and its agencies or consultants, even when such 'productivity' is at odds with local people's goals, can be seen as constituting the colonial present.

Second, many projects of colonial conquest were justified on the basis of 'guardianship' or 'trusteeship', concepts that are grounded in the idea of saving or civilising the 'conquered' people (Allsobrook and Boisen 2017, 265). In other words, these land dispossessions were framed under the guise of improvement, welfare and development of the people concerned (Miller et al. 2010). As Allsobrook and Boisen (2017, 265) point out, the idea of trusteeship legitimises the rule of the capable on behalf of the incapable. Trusteeship is 
evident in all three aspects of land reform in South Africa (redistribution, restitution and tenure reform). In land redistribution, PLAS's condition that the state will remain owners of the land, and that a condition for receiving funding and other production support beneficiaries should have strategic partners or mentors (almost always white, thus far) (Hall and Kepe 2017), uses the same colonial logic of trusteeship to continue to keep black people subservient, despite the rhetoric of justice.

An example of trusteeship in land restitution is explained in detail in Kepe (2012), where in the case of successful land claims on nature reserves and parks the claimants are forbidden from changing the land use of the area in question, while the state, a conservation agency or department remains the manager of the protected area. As Kepe shows, even in the ceremonies to hand over successfully claimed land to claimants, state officials make statements that leave the question of who has stronger rights on the land - the claimants or the state - unclear. In the area of land tenure reform, rural areas where blacks have had insecure land rights throughout apartheid, and land was held in trust by the state, land reform has yet to change the status quo. Land in these areas is still held in trust by the state, represented by the Minister of Rural Development and Land Reform, with traditional leaders who were installed by the apartheid regime remaining as custodians on behalf of the occupiers and de facto owners (Ainslie and Kepe 2016). There is therefore no denying that continuing trusteeship in all areas of land reform constitutes the colonial present.

\section{A big fat paradox: land becoming less important? Less land for black people?}

Alongside the proclaimed centrality of land reform to 'radical economic transformation' we see instead a dramatically declining budget being allocated, currently sitting at $0.4 \%$ of the national budget. This, alongside the diversion of funds away from land acquisition towards the Minister's pet project of agro-industrialised 'Agriparks', means that land reform has almost ground to a halt. Where it is happening, land reform is increasingly taking place through strategic partnership and other institutional forms that prevent black people from getting and controlling land themselves. Instead, the state is the 'willing buyer' which is buying up land at market price and retaining ownership, allocating use rights or leaseholds, often to white-owned companies or multinationals, while signing up farm workers as 'beneficiaries' who are expected to benefit via dividends.

Our initial research in the Eastern Cape finds that the farm workers do not control either the land or production, and in no cases could we find that they had benefitted financially. Instead, some within both the citrus and chicory sectors were being paid below-minimum wage on farms bought by the state, ostensibly for them (Hall and Kepe 2017). All this needs to be understood in a context where the state is now wary of transferring full control over land to beneficiaries, preferring to keep production going via such joint ventures, and also favouring certain companies with politically connected black economic empowerment partners. Also benefitting are black businesspeople who are able to capitalise their farms from other sources and are first in line to receive state funding via a Recapitalisation and Development Programme. On the margins are farm workers, who

\section{http://repository.uwc.ac.za}


typically lose their jobs when the state purchases farms, in the interregnum prior to allocation to new 'beneficiaries'. We find that questions of labour and the relations of farm workers to the land have been elided as the land reform programme has taken its turn towards perpetuating existing commercial farming models and addressing elite interests.

Several ideological and implementation contradictions are evident in PLAS that render the idea of land reform's ideal of justice a mere illusion. The first is that PLAS is framed in terms of 'efficiency', productivity and commercial farming units. This means that where this productive efficiency in a commercial farming setting does not exist, land reform beneficiaries face threats of having their land taken away. This is no different from the colonial logic of justifying conquest of certain lands simply because they were deemed unproductive in their land use. The problem with this logic, then and now, is that the same people who had power, and used violence against the legal owners of the land defined this notion of productivity.

The second issue with PLAS is that of trusteeship, whereby the state does not transfer title or other independent tenure rights to the land reform beneficiaries. Trusteeship was another justification used in colonising indigenous people around the world, using an argument that those who are capable can, and should, assist those who are incapable. Of course, trusteeship creates a state of patronage and a patronising state: beneficiaries rely on the largesse of the state, irrespective of any discontent they may feel. State officials control even the smallest aspects of life of on these land redistribution farms. For example, state officials expect land reform beneficiaries to seek permission for simple livelihood activities such as piping water to the homesteads from a borehole meant for livestock.

The last example, which is related to trusteeship, is that of the requirement by PLAS that black beneficiaries need to have a mentor or a strategic partner before they can receive any financial production support from the state. Thus far, the vast majority of the mentors or strategic partners are white farmers or large agri-business corporations. In the case of both strategic partners and mentors, beneficiaries often find themselves as simply labourers on the land they were supposed to hold as primary beneficiaries (Hall and Kepe 2017).

\section{Conclusions}

The importance of land as a symbol of colonial conquest, as well as a symbol of resistance against colonialism and apartheid, made it a pivotal issue in the negotiations for ending apartheid. This gave birth to the current land reform programme that has been good on paper but being poorly implemented (Hebinck and Cousins 2013). Critical scholars have zeroed in on the failure of land reform to return dignity to victims of racist land policies and have questioned the notion of a decolonised South Africa if land reform is not coupled with a broader agenda to provide justice, emancipation and freedom to apartheid victims (Andrews 2006; Atuahene 2007; Hendricks, Ntsebeza, and Helliker 2013; McCusker, Moseley, and Ramutsindela 2016). 
In addition to the well-publicised critiques of South Africa's land reform programme, particularly its inability thus far to improve the welfare of, and its failure to bring about land justice, land reform is indifferent to the many and diverse meanings of land to different people in the country. In particular, land reform's obsession with productivity of land in terms of agriculture as discussed above marginalises these other meanings of land. It has now been shown in many studies that land has multiple meanings that go beyond its use as a natural resource for agriculture, collection of wild resources, shelter and recreation, to mention a few (Kepe, Hall, and Cousins 2008; Ferguson 2013; Li 2014). These meanings can include land as a form of identity for the people concerned, due to their historical roots to it; it could also of sentimental value as a result of ancestral graves or other rituals that are attached to the area; and it could serve as a bargaining power to leverage resources or other concessions that strengthen political positions and contribute to livelihoods (Marco-Thyse 2006; Kepe, Hall, and Cousins 2008; James 2009; Li 2014).

What can land mean - other than a commodity? As identity, home, family, heritage, livelihood and many other meanings, land plays a crucial role in people's understandings of themselves in the world. A growing body of opinion in South Africa argues not merely for a return of land lost, but for a new relationship with land, one that returns to a precommodification notion of land, in which land is not merely 'owned' but that people identify with and are instead 'owned by' the land (Krog 2015). As a result, two competing narratives animate debates on land. On the one hand, land as a common national resource should be optimally used, and those unable to make optimal use of it should cease to hold it. On the other hand, entitlements to land are based on historical and heritage principles, and arguments of indigeneity, and so rights to land should not be held contingent on economic considerations or productive use. Rather, people should hold the land because it is theirs, not because it is efficiently used.

The tensions between the EEF and the ANC on the land question show how contestations over land are increasingly inserted in the public sphere. At the same time, studies on racially differentiated perceptions on land in post-apartheid South Africa (Gibson 2010) show that the majority of blacks in South Africa still believe that the land reform programme has not done much to contribute to colonial and apartheid land injustices and consider it an outstanding political grievance.

Our paper is a modest attempt to reinsert this general discontent about the failure of land reform in the debates about decolonisation, as well as to point to contradictions that exist between the rhetoric of justice from the state and reality on the ground. Our brief example of land redistribution under the current PLAS policy illustrates how, rather than decolonisation being evident in land reform, the colonial present is more of a reality.

In conclusion, whereas in the past people contested the state during colonialism and apartheid, now, through paternalism and disdain for dissent, the state makes it almost impossible for isolated land reform beneficiaries on the PLAS farms to organise against it. We believe that this point alone should be enough for any constituencies of the South 
African society who care about justice, freedom and emancipation of the formerly oppressed, to stand up and use their voices to call land reform for what it is - the colonial present, and therefore far from serving the interest of a true decolonisation. Perhaps this can be a collaborative approach among those based in academic institutions and the public, including land reform beneficiaries themselves. If land was central to colonialism and the struggle against it, then land should be central to decolonisation, and it should be in the interest of all to push towards decolonisation in all its facets.

\section{Disclosure statement}

No potential conflict of interest was reported by the authors.

\section{Funding}

This research was supported by the Social Sciences and Humanities Research Council (SSHRC) of Canada (grant number 435-2014-0825). 


\section{References}

Ainslie, A., and T. Kepe. 2016. "Understanding the Resurgence of Traditional Authorities in Post-apartheid South Africa.” Journal of Southern African Studies 42 (1): 19-33.

Allsobrook, C., and C. Boisen. 2017. "Two Types of Trusteeship in South Africa: From Subjugation to Separate Development." Politikon 44 (2): 265-285.

Andrews, M. 2006. "Struggling for a Life in Dignity." In The Land Question in South Africa: The Challenge of Transformation and Reconciliation, edited by $\mathrm{L}$. Ntsebeza, and R. Hall, 202-219. Cape Town: HSRC Press.

Atuahene, B. 2007. "From Reparation to Restoration: Moving Beyond Restoring Property Rights to Restoring Political and Economic Visibility." SMU Law Review 60 (4): 1419-1470.

Bendile, Dineo. 2017a. “ANC Plans 'Constitutional Revolution' on Land.” Mail \& Guardian, February 3. Accessed February 3, 2017. https://mg.co.za/article/2017-02-03-00anc-hits-warp-speed-on-land.

Bendile, Dineo. 2017b. "ANC Kicks Off Land Debate Amid Divided Views from Leaders." Mail \& Guardian, February 24. Accessed February 24, 2017. https://mg.co.za/article/2017-03-12-anc-kicks-off-land-debate-amid-divided-viewsfrom-leaders.

Boisen, C. 2017. "From Land Dispossession to Land Restitution: European Land Rights in South Africa." Settler Colonial Studies 7 (3): 321-339.

Eze, C. 2015. "Decolonisation and Its Discontents: Thoughts on the Postcolonial African Moral Self." South African Journal of Philosophy 34 (4): 408-418.

Ferguson, J. 2013. "How to Do Things with Land: A Distributive Perspective on Rural Livelihoods in Southern Africa." Journal of Agrarian Change 13 (1): 166-174.

Fraser, A. 2007. "Land Reform in South Africa and the Colonial Present." Social \& Cultural Geography 8 (6): 835-851.

Gibson, J. L. 2010. "Land Redistribution/Restitution in South Africa: A Model of Multiple Values, as the Past Meets the Present." British Journal of Political Science 40: 135169.

Gregory, Derek. 2004. The Colonial Present: Afghanistan, Palestine, Iraq. Oxford: Blackwell.

Gutto, S. B. O. 2014. "Re-theorising and Re-conceptualising Land, Sovereignty, Socioeconomic Rights and Responsibility in the Context of Pan-Africanism and African Renaissance in the 21st Century." International Journal of African Renaissance Studies 9 (1): 5-15.

Hack, K. 2008. International Encyclopedia of the Social Sciences. Detroit: Macmillan Reference USA, 255-257.

Hall, R., and T. Kepe. 2017. "Elite Capture and State Neglect: New Evidence on South Africa's Land Reform." Review of African Political Economy 44 (151): 122-130.

Harris, C. 2004. "How Did Colonialism Dispossess? Comments from the Edge of Empire." Annals of the Association of Geographers 94 (1): 165-182.

Hebinck and Cousins. 2013. In the Shadow of Policy: Every day Practices in South African Land and Agrarian Reform. Johannesburg: Wits University Press. 
Hendricks, F., L. Ntsebeza, and K. Helliker 2013. The Promise of Land: Undoing a Century of Dispossession in South Africa. Auckland Park: Jacana Media.

James, D. 2009. "Burial Sites, Informal Rights and Lost Kingdoms: Contesting Land Claims in Mpumalanga, South Africa." Africa 79 (2): 228-251.

Kepe, T. 2012. "Land and Justice in South Africa: Exploring the Ambiguous Role of the State in the Land Claims Process." African and Asian Studies 11 (4): 391-409.

Kepe, T., and R. Hall. 2016. "Land, Politics and Policy Change in South Africa: What Questions for Land Redistribution Policy and Practice?” In Domains of Freedom: Justice, Citizenship and Social Change in South Africa, edited by T. Kepe, M. Levin, and B. von Lieres, 27-39. Cape Town: University of Cape Town Press.

Kepe, T., R. Hall, and B. Cousins. 2008. "Land." In The New South African Key Words, edited by N. Sheppard, and S. Robins, 143-156. Athens: Ohio University Press and Johannesburg: Jacana Media. Kepe, T., and D. Tessaro. 2014. "Trading-off: Rural Food Security and Land Rights in South Africa." Land Use Policy 36: 267-274.

Krog, Antjie. 2015. "Baas van die plaas/Izwe lethu: Essay in Fragments and Two Villanells Exploring Different Relationships to Land in Some Indigenous Poetic Texts." In Land Divided, Land Restored: Land Reform in South Africa in the 21st Century, edited by Ben Cousins and Cherryl Walker, 206-231. Cape Town: Jacana.

Levin, M., T. Kepe, and B. von Lieres. 2016. "Introduction." In Domains of Freedom: Justice, Citizenship and Social Change in South Africa, edited by T. Kepe, M. Levin, and B. von Lieres, 1-20. Cape Town: University of Cape Town Press.

Li, T. M. 2014. "What Is Land? Assembling a Resource for Global Investment." Transactions of the Institute of British Geographers 39 (4): 589-602.

Marco-Thyse, S. 2006. "Land Rights in South Africa: A Mechanism Against Poverty?" Development 49 (3): 133-137.

Mbembe, A. 2008. "Passages to Freedom: The Politics of Racial Reconciliation in South Africa.” Public Culture 20 (1): 5-18.

McCusker, B., W. G. Moseley, and M. Ramutsindela. 2016. Land Reform in South Africa: An Uneven Transformation. London: Rowman \& Little Field.

Miller, R. J., J. Ruru, L. Behrendt, and T. Lindberg. 2010. Discovering Indigenous Lands: The Doctrine of Discovery in the English Colonies. Oxford: Oxford University Press.

Mkokeli, Sam, and Mike Cohen. 2017. "ANC Backs Just, Equitable Compensation for Land." Fin24.

Accessed March 13, 2017. http://www.fin24.com/Economy/anc-backs-justequitable-compensation-for-land-20170313.

Ncana, N. 2010. "Unproductive Farms to be Seized." Sunday Times Live, March 25. Accessed October 8, 2017. https://www.timeslive.co.za/news/south-africa/2010-03-24unproductive-farms-to-be- seized/.

Ndlovu-Gatsheni, S. J. 2012. "Fiftieth Anniversary of Decolonisation in Africa: A Moment of Celebration or Critical Reflection?" Third World Quarterly 33 (1): 71-89.

Ndlovu-Gatsheni, S. J. 2013. Coloniality of Power in Postcolonial Africa. Myths of Decolonisation. Dakar: Codesria.

Radebe, H. 2012. "Minister Gives Farmers Five Years to Get it Right." Business Day, August 20. 
Saul, J. S. 2012. "Transition in South Africa: Choice, Fate ... or Recolonisation?" Critical Arts 26 (4): 588-605. 